\title{
Teaching NeuroImages: Optic and third cranial nerves infiltration as initial relapse of acute lymphoblastic leukemia
}

Natalia Shor, MD, Christine Fardeau, MD, and Sophie Bonnin, MD

Neurology ${ }^{\circledR}$ 2019;93:e829-e830. doi:10.1212/WNL.0000000000007979

A 34-year-old man with a history of acute lymphoblastic leukemia (ALL) under consolidation treatment presented right-side blurred vision and headache associated with complete third right cranial nerve palsy. Brain MRI (figure, A-E) revealed thickening of the right optic and third nerves. Fundus examination (figure, F) found Roth spots, which are

Figure Brain MRI and right eye fundus examination

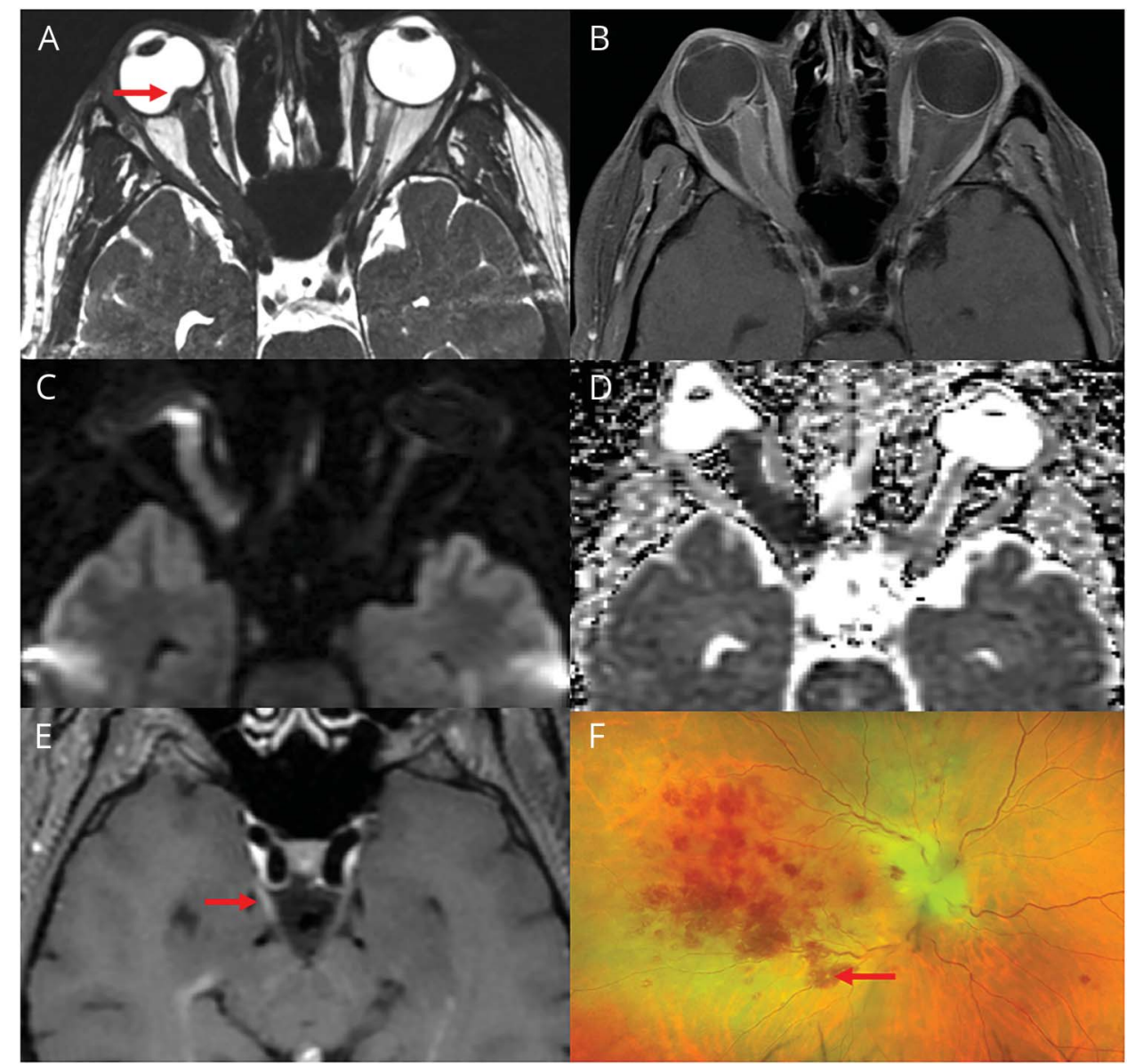

T2 sequence ( $A$ ) reveals enlargement and papillary edema ( $A$, arrow) of the right optic nerve. Gadolinium-enhanced fat-saturated T1-weighted imaging ( $B$ and $E$ ) shows thickening and abnormal enhancement of right optic and third cranial nerves (E, arrow). The optic nerve displays diffusion hyperintensity $(C)$ and a very low signal on apparent diffusion coefficient map (D). Roth spots are seen on fundus examination ( $F$, arrow).

\section{Figure Brain MRI and right eye fundus examination}

Correspondence

Dr. Shor

natalia.shor@aphp.fr

\section{MORE ONLINE}

\section{$\rightarrow$ Teaching slides}

links.lww.com/WNL/

A944 
highly suggestive of retinal leukemic infiltration. ${ }^{1}$ Lumbar puncture revealed blast cells. Other possible differentials were excluded. The right-side headache was probably due to ischemic changes of the nerves secondary to the leukemic infiltration.

Awareness of cranial nerves involvement in ALL is important as it may be a sign of leukemia recurrence. ${ }^{2}$

\section{Disclosure}

The authors report no disclosures relevant to the manuscript. Go to Neurology.org/N for full disclosures.

\section{Study funding}

No targeted funding reported.

\section{Appendix Authors}

\begin{tabular}{llll}
\hline Name & Location & Role & Contribution \\
\hline $\begin{array}{l}\text { Natalia } \\
\text { Shor, MD }\end{array}$ & $\begin{array}{l}\text { Hôpital de la Pitié- } \\
\text { Salpêtrière, Paris, } \\
\text { France }\end{array}$ & Author & $\begin{array}{l}\text { Acquisition and } \\
\text { interpretation of data, } \\
\text { drafted the manuscript for } \\
\text { intellectual content }\end{array}$ \\
\hline $\begin{array}{l}\text { Christine } \\
\text { Fardeau, } \\
\text { MD }\end{array}$ & $\begin{array}{l}\text { Hôpital de la Pitié- } \\
\text { Salpêtrière, Paris, }\end{array}$ & Author & $\begin{array}{l}\text { Revised the manuscript for } \\
\text { intellectual content }\end{array}$ \\
\hline $\begin{array}{l}\text { Sophie } \\
\text { Bonnin, } \\
\text { MD }\end{array}$ & $\begin{array}{l}\text { Hôpital de la Pitié- } \\
\text { Salpêtrière, Paris, }\end{array}$ & Author & $\begin{array}{l}\text { Acquisition and } \\
\text { interpretation of data, } \\
\text { revised the manuscript for } \\
\text { intellectual content }\end{array}$ \\
\hline
\end{tabular}

\section{References}

1. Varga Z, Pavlu J. Images in clinical medicine: Roth's spots. N Engl J Med 2005;353:1041.

2. Sharma T, Grewal J, Gupta S, Murray PI. Ophthalmic manifestations of acute leukaemias: the ophthalmologist's role. Eye 2004;18:663-672. 


\section{Neurology}

Teaching NeuroImages: Optic and third cranial nerves infiltration as initial relapse of acute lymphoblastic leukemia

Natalia Shor, Christine Fardeau and Sophie Bonnin

Neurology 2019;93;e829-e830

DOI 10.1212/WNL.0000000000007979

This information is current as of August 19, 2019

\section{Updated Information \&} Services

References

Subspecialty Collections

Permissions \& Licensing

Reprints including high resolution figures, can be found at: http://n.neurology.org/content/93/8/e829.full

This article cites 2 articles, 0 of which you can access for free at: http://n.neurology.org/content/93/8/e829.full\#ref-list-1

This article, along with others on similar topics, appears in the following collection(s):

Cranial neuropathy

http://n.neurology.org/cgi/collection/cranial_neuropathy

MRI

http://n.neurology.org/cgi/collection/mri

Optic nerve

http://n.neurology.org/cgi/collection/optic_nerve

Information about reproducing this article in parts (figures,tables) or in its entirety can be found online at:

http://www.neurology.org/about/about_the_journal\#permissions

Information about ordering reprints can be found online:

http://n.neurology.org/subscribers/advertise

Neurology ${ }^{\circledR}$ is the official journal of the American Academy of Neurology. Published continuously since 1951, it is now a weekly with 48 issues per year. Copyright @ 2019 American Academy of Neurology. All rights reserved. Print ISSN: 0028-3878. Online ISSN: 1526-632X.

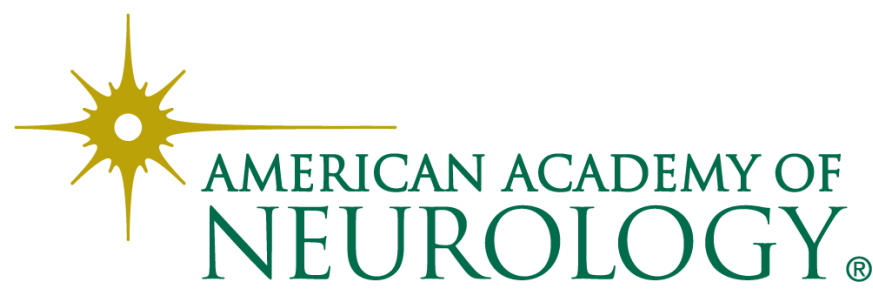

